\title{
Measuring Literary Sides of Tuan Guru Abdul Madjid's Creative Work Wasiat Renungan Masa Pengalaman Baru: A Study on the Most Influential Spiritual Leader of Lombok Island
}

\author{
Nuriadi and Sribagus \\ Faculty of Teacher Training and Education, University of Mataram, Lombok, Indonesia \\ Corresponding authors: Nuriadi; nuriadi@unram.ac.id. and Sribagus; sribagus@unram,ac.id
}

Received 20 August 2019;

Accepted 29 August 2019;

Published 01 September 2019

\begin{abstract}
This paper is intended to discuss how far literary side of Mualana Syekh TGKH Muhammad Zainul Abdul Madjid's work, from Pancor, East Lombok, West Nusa Tenggara province entitled "Wasiat Renungan Masa Pengalaman Baru" (Advice of New Experience Era Contemplation). Maulana Syekh TGKH Muhammad Zainul Abdul Madjid is the Indonesian national hero and the most influential spiritual leader from Lombok. $\mathrm{He}$ is also known as a literary writer. Specifically, this paper tries to evaluate proper or not this work to be categorized as a literary work particularly in sense of its form and content. The discussion of this work is important since it has become one of the main references by Nahdhatul Wathan's followers, an Islamic organization developing largely in Lombok and West Nusa Tenggara Province. The discussion of this work is hoped then as a way to know further the uniqueness of the work so anything comes up from the work able to be a representation of Indonesians or Malayans' identity from West Nusa Tenggara. Therefore, this paper more or less can show how big the writer is in sense of being an inspirator for all Sasak people and West Nusa Tenggara people. In this regard, this paper tries to analyze literary sides of the work by using a simple logic from structuralism theory especially initialized by American structuralists in the New Criticism School.
\end{abstract}

Keywords: literature, advice, form, content, $N W$, figure, tuan guru, structuralism.

\section{Introduction}

Maulana Syekh is the famous nick name of Tuan Guru Kiyai Haji (TGKH) Muhammad Zainul Abdul Madjid, a great Moslem leader in Lombok. Not only is he a great leader in Lombok but also over the world since he has been awarded National Hero title by the government in November 2017 (www.suarantb.com). Before that he was awarded "Bintang Maha Putra" title by President Abdurrahman Wahid, the third Indonesian president, due to his works, dedication, and legacies in developing Islamic education in Lombok. Since 1936, Maulana Syekh founded Madrasah Diniyah Islamiyah. This school had vision to educate people from all parts of West Nusa Tenggara Province in particular from which he implemented his vision that the only one way to effectively achieve enlightenment for people is through education. It, in fact, becomes a vein of human beings' civilization. Therefore, afterwards, he totally dedicated his life for education and founded many Pesantren or Islamic boarding schools (Effendi, 2015: 15).

He was born at Bermi village, Pancor, East Lombok, West Nusa Tenggara on 17 Rabiul Awal 1316 Hijriah (Islamic calender) coincided with August the fifth 1898. His father was Tuan Guru
Haji Abdul Majid who was more intimately called Guru Mukminah or Guru Minah. His mother was a religious/godly woman, Hajjah Halimah al-Sa'diyah. His given name was Muhammad Saggaf, a name which was based on an event that was deeply worth learning; three days before he was born, his father was visited by two holy persons (waliyullah). One of them was from Hadramaut and the other one was from Magrabi. Both of the holy persons happened to have the same name "Saqqaf". The holy persons recommended TGH Abdul Madjid to give a name to his new born baby "Saqqaf" which literally means "the Roof" of the holy persons at his Era.

The word "Saqqaf" became Saggaf in Indonesian and switched to "Segep" in Sasak accent. Therefore he was oftenly called "Gep" by his mother, Hajjah Halimah al-Sa'diyah (www.id.wikipedia.org, 2014).

His characterization started from his initiative to build religious as well as communial organization, Nahdatul Wathan (NW), which was parallel to Nahdatul Ulama' (NU) and Muhammadiyah organization in Java. This organization (NW) was built in Pancor, east Lombok on 1 March 1953 coincided with 15 Jumadil Akhir 1372 Hijriah (www.id.wikipedia.org, 2014). Starting from his 
serious initiative in developing this organization designated from building traditional Muslim schools and education institution, this organization had specilal characteristic since it showed obvious contribution towards Islam progress in Lombok. Since then, his love and national vision as a religious and social leader was natioanally known, so that his role and leadership started to be considered.

This was supported not only by his profound religious knowledge and his holiness but also by his vision and creativity in Islamic art and literature. His aspiration, thought, and bright futuristic view are clearly depicted in his literary work. Two of them are HIZIB containing collections of Arabic prayers, and "Wasiat Renungan Masa Pengalaman Baru" (Advice of New Experiences Era Contemplation).

With regard to this, this article specifically tries to thoughtfully look at his book entitles "Advice of New Experience Era Contemplation" in literary perspective. It will weigh how far its literary aspect is from the content and form sides so that this book is eligible to be comprehended and becoming public readers especially for recent NW followers after he passed away. Besides, this article tries to prove his famous name as a great figure in Lombok so that he deserves affirmation as leader and inspirator of West Nusa Tenggara people in particular and people of Indonesia in general in terms of his contribution for people and nation. This is important, for Indonesian people are now doubtful in determining selfness and significance because there is very little appreciation of youngsters toward local and national figures who have devoted their time and lives for the development of societies and nation.

\section{Theoretical Framework}

For that purpose, this article uses a simple perspective initiated by the theory of Structuralism, especifically the one displayed by the Structuralists from the New Criticism school from America developing in the midst of the 20th century. The main concept is actually not far different from the ones in Europe, saying that literary work is ergocentric; it means that it has an otonomous world, which is free or excluded from extrinsic aspects, especially from the writer's background and interpretation from the audiences.

From this concept, every part in literary work - intrinsic elements - has unity, interdependence, coherence, plays important and the same role in building artistic and aesthetic facets of a literary work to deliver the message to ther eaders (see Endraswara, 2003). Nevertheless, specifically Structuralists dichotomically divide literary work into two aspects: form and content. In relation to this, Leitch (1944: 54) further explains this notion, as follows:

By comparison, New Critical interest poetic instrumentation, in genre, and in prose form was scant and nonsystematic. Whereas the New Critics studied the convergence of elements in a textual structure, the Russian formalists examined the deviation of elements against the ground of literary norms. New Critical formalists were committed to unified structure and unified sensibility as standards of poetic perfection. Such values and judicial criticism played little role for the Russian formalists.

Hence, Rene Wellek and Austin Warren, the two followers of New Criticism state further in their book entitles Theory of Literature (1977) that to examine a literary work, it is necessary to focus on the form and content aspects. Both are inseparable because in Structuralism perspective they support each other in delivering message, existence and literary aesthetic cohesively and coherently. Based on this argument Maulana Shekh's book can be acknowledged as a creative work or, more precisely, a literary work which involves vivid personality and fictionality of the writer in the writing process.

Georgy Castle in The Blackwell Guide to Literary Theory (2007) says that the first judgment toward a work whether or not to claim it as a literary work lies on the degree of someone's creativity. For this reason, it is clear that the work discussed in this article is, in my opinion, work of art or literary work. In order to prove the literary qualification in this book, we'd better look at it from the form and content aspects as Rene Wellek and Austin Warren mention above.

\section{The Form and Content Aspects of the Work}

\subsection{Form Aspect: the Language Expressions}

Firstly, why is this work entitled "Advice of New Experience Era Contemplation"? More specificaly, "what is the matter with the phrase "New Experience"? In my opinion the title implies that there is a phase/time difference where Maulana Syekh himself as the writer and the character has experienced two different eras : Old and New ones. Old era produces old experience, and New era produces new experience. In this context, Old era refers to the time when he was young or NW organization was still new so that sociologically his Durkheimian was only a few and the organization he built was relatively till small with firm mass cohesivity. Meanwhile, New era which produces new experience can refer to today's era, exactly since 1970ies up to this present time (within the time interval) NW organization has developed quickly and has complex experience. Consequently he, as a great holy man with bright future vision thinks it necessary to leave "Advice" to the new followers for the sustainability.

Next, from content aspect, this work consists of four kinds of advice which were written at different time: (a) Advice on 23 September 1973, (b) Advice on 7 October 1981, (c) Advice on 1 March 1970, (d) Advice on 28 September 1970. The presence of those four kinds of Advice is not chronologically ordered. Probably, the editor had strong reasons not to do it as it was supposed to be. One of the reasons, is related to the stressing on the content or the message of each part of the Advice instead of on the tecgnical reason. Besides the four kinds of Advice, this book is equipped with edition preface and other additions such as "Iqrar Baiat" and Arabic prayers at the ending part of the book.

The Advice which was written on 23 September is short enough, not more than one page, in positive statements, not in poetic expression with strong sound and rhyme. Thus the message can be understood directly without pre intensive reading. To put it in other words, the Advice uses daily language (primary modeling language system) as Yuri Lotman puts it in theory.

Different from the prvious Advice, the Advice on 7 October 1981 is written in specific pattern. It is specific because it is presented in consistent stanza. Each stanza consists of four lines, and each line consists of four words in average, although in cerain lines there can be 3 or 5 words depending upon the length of certain words and the number syllable in them. With stanza form division, it can be seen that there are 233 pieces/stanzas of advice presented. This is in fact the longest advice of Maulana Syekh.

Besides, with four lines in one stanza, in a glance, this pattern is close to traditional poem prototype - Indonesian Old literature. However, such judgement is not definitely correct because poem modle has two couplets (the first two lines) and content (the second two lines) with rhyming modle (a-b-a-b). The Advice of Mauana 
Syekh is not like this. There is no couplet; all of them are content with constant rhymes (a-a-a-a) which are due to phonetic sound (the same vowel or consonant at the end of each line) like: ziarah, madrasah, ruhaniyah, and Ka'bah, in stanza 51. Here lies the interesting point since all of them can automatically give the readers poetic or aesthetic effect, so they can enjoy either the content aspect of the message or various artistic presence of form aspect.

Another unique thing in this Advice is that in each topic movement/change, there is expression Subhanallah walhamdulillahi wala ilaaha illallah wallahu akbar walillahilhamd. This movement signal implies that the topic concerned is directly related to religion problem or theology which is traditional in NW so far. Such movement signal reminds me of narrative model which commonly appears in old literary work generally delivered in small parts (PUH PUH). One part (Puh) discusses one topic or theme. It is approximately the same as this second Advice.

In terms of dictions, Maulana Shekh is creative enough because he uses the polysemic ones with strong connotation such as the words CUPAK (a character), KURSI (chair), PIRING (plate), RANJANG (bed), and so on. Cupak refers to a character in Cupak Gurantang story (falklore) which represents a man who is lazy, greedy, liar, loves/likes doing bad things just for self ambition. "Kursi" represents secular power, not a chair in lexical or denotative meaning. Piring symbolizes the source of income which is secularly sought by everybody. Ranjang is the symbol of peace, safety, and wealth. All of these words are metaphorical with connotative meaning and in Maulana Syekh's view these characteristics can make people forget the religion and the hereafter.

He is said to be creative in using three sources of dictions from three languages: Indonesian, Arabic, and Sasak. Although he mainly uses Indonesian, it does not mean that he's got hindrance in applying Arabic terminology and Sasak expressions in lines.

Combination of dictions fom three languages is not a problem. It instead shows creativity and fictionality of the author. He, as if, had to select the dictions in such a way in ordr to match the sound with the previous rhyme without having to ignore the intended message. However, from the editting technical side, it is very good if the particular Sasak dictions are given foot notes or glossary at the end of the book.

The artistic creativity of Maulana Syekh continues to Advice 1 March 1970, consisting of 112 stanzas. Besides consistantly using the same and tough rhyme as he does in the previous Advice (a-aa-a), this Advice consists of five lines in each stanza. The fifth line is the expression Aduh sayang. Accordingly, if "aduh sayang" is placed as the first line, the rhyme becomes a-b-b-b-b.

Aduh sayang surely implies that the audiences are those who are loved by Maulana Syekh; the students or loyal followers, or people who become parts of NW organization so far. The use of aduh sayang, in oponion, can raise strong close psychological effect to the audiences so that his message can be easily accepted and comprehended. In other words, aduh sayang expression can increase emotional relationship between maulana Syekh as a teacher and his students, readers, and followers. This is further enriched with his skill in playing with dictions in every line of the Advice. For semantically strong and important dictions he uses capital letters. Especially for Advice of the 1st March 1970, the use of capital letters is striking enough as can be seen below (quoted from the Advice, stanza 33).

Aduh sayang!
Jauhkan dirimu dari CUPAK

Karena Cupak sangat merusak

Asal dijanji KURSI dan PERAK

Tidak perduli GURU dan SANAK

(Oh, dear!

Be far away from CUPAK

Cupak is destructive

Promised with CHAIR and SILVER

Ignores TEACHER and BROTHER)

Advice 28 September 1970 is additional as the title says. Nevertheless, from content and form sides, it is not merely an addition. It has its own meaning, so that it is eligeble to read and take it into account as advice from the great holy person in Lombok. Factually it has similar form with Advice 1 March 1970: (1) both consist of five lines, the first of which is expression aduh sayang. (b). both use the same and constant rhyme (a-b-b-b-b). What makes it different from the previous Advice is the use of figurative language in the last line of each stanza which is written in capital letters. The use of figure of speech adds aesthetic effect and strengthens the Advice. See exmple in Stanza 1.

\section{Aduh sayang \\ Wahai anakku Rauhun Rehanun, \\ Tetapkan dirimu selangkah seayun \\ Membela NW turun temurun \\ BERTETANGGA NAIK BERJENJANG TURUN}

(Oh, dear!

$\mathrm{Hi}$, my daughter Rauhun, Rehanun

Keep yourself in harmony

Defend NW continuesly

UP AND DOWN ALWAYS TOGETHER)

Thus the first Advice is presented in daily language, so that its form is proposition. Meanwhile the second, the third, and the fourth collections are arranged on the form of poem, using selected dictions, strong and constant rhyme, and need deeper attention for further understanding. With such kind of form, the Advice can be more interesting and aesthetic to the readers.

\subsection{Content Aspect: Reading Signs of the Time}

Content is the essence, message, or purpose of creative literary work. This is important point to be understood and acted/made concrete by the audiences. In general, all pieces of Advice by Maulana Syekh are leading the audiences to do good things (amar ma'ruf) and avoid the bad ones (nahi munkar). He does all these due to his love and care to NW people, students, strick followers in particular, and to Lombok people in general who whether want to or not undergo New era with complex experiences. In other words, the presence of this Advice is the representation of the reading of the "Semiotka Jaman" (reading sign of the times) which he has seen long time ago. In other words, (1) the presence of this Advice - which is applicable enough in this era indicates the superiority of Maulana Syekh as a futurolog. He can predict the condition of the Era long time before it happens. He had predicted the future era condition, and the fact shows it happens now. People will be greedy, consentrate more on secular matters/aspects, and are willing to do anything to achieve individual ambition or group concern. (2) hence, this Advice book seems to be a work which was - is useful and will exist continously. (3), the presence of this Advice is important beause the condition of the Era must be complex, and most people are in total disassary by ambition.

Semiotic/Sign reading by Maulana Syekh basically covers several things: 1. Religion, 2. Nationality, 3. Character, 4. 
Sasakness, 5. NW organization. Firstly, the Advice is heavily focussed on aqidah grading, strengthening belief in God, and obidience toward al-Qur'an Hadits. Examples for those topics are seen in Stanzas 67, 68, and so forth.

\section{Kita berada di abad Final \\ Di abad 'YAHIN' sudah terkenal \\ Iman taqwa jangan dijual \\ Jangan digadai pada "Sang Dajjal" \\ Hidupkan iman hidupkan taqwa \\ Agar hiduplah semua jiwa \\ Cinta teguh pada agama \\ Cinta kokoh pada negara}

(We are at Final decade

"YAHIN" decade is wellknown

Don't sell Iman and Taqwa

Don't pawn to Dajjal)

(Live Iman and Taqwa

For entire souls to live

Firmly love the religion

Strongly love the country)

Secondly is the nationality of Indonesia. Here Maulana Syekh motivates his followers to continuously get involved in an effort to develop the nation and the country, to participate in all aspects of development as the initial philosophy of the existence of NWDI organization: love and devotion to the development of the nation. NW comes as the media to devote himself and his followers. Of course, this implies that Maulana Syekh is nationalist of Indonesia. One of the Advice which is relevant to that is:

Aduh sayang!
Pelita NTB bertambah terangnya
Karena NW lahir padanya
Berpartisipasi dengan megahnya
MEMBELA AGAMA NUSA DAN BANGSA

(Oh, dear!

Light of NTB gets brighter

'Cause NW grows there

Participating in glamour

DEFENDING MEN, RELIGION, AND NATION)

The third case strengthened in Era reading is the behaviour/character. In regard to this, Maulana Syekh is so concerned that almost in every collection of his Advice, this actually becomes his main attentin. Related to character here he highlights not to become secular people, ambitious and so on. According to him, this is identical to leaving/missing the religion, dignity respect, and the familiarity of the NWDI. Stanzas 104 and 119 show that.

Terkadang menjual jiwa raganya Menjual taqwa menjual imannya

Itu terjadi karena gilanya

Ditawan syaitan dan hawa nafsunya

Bila seseorang kehilangan akhlak

Dhahir batinnya suka memberak

Ibu bapaknya dipandang budak

Bila tak dapat emas dan perak

(Sometimes selling his life and soul

Selling his Iman and Taqwa

Because of his crazyness

Under devil and passion control)
(If man loses character

Personally likes defecating

Seeing his parents as slaves

If he misses gold and silver)

The fourth case - in my view- which belongs to his concern is about Sasakness. This is important because "Sasak people" is seen as typical people. Typicality is meant Sasak people are Moslem. If they are not Moslem, they don't belong to Sasak People. It means, to become totally Sasak man, one must be loyal to Islam, always firm and upright like Mount Rinjani. In that way he will become a patient, sincere, and brave man. Advice which points to that is Stanza 124 and 231.
Janganlah nanda mau diajak!
Ikut serta merusakkan Sasak!
Jangan terlena pepatah Sasak:
'Dengan Sasak girang gerasak'!
Tegakkan Sasak setegak Rinjani
Membela iman membela diri..
Tegak utuh ikhlas berani ...
Tidak tertawan ajaran Iblisi.....
(Say no for request
To destroy Sasak
Don't be tempted by Sasak proverb
Sasak people like joking)
(Hold up Sasak firm like Rinjani
Defend belief and self
Strong, sincere, and brave
Far away from devils)

The fifth, the most important one, to build, develop, and sustain the vision, mission, and value of NWDI organization. This is more specifically aimed at his followers and students. In this context he more oftently uses Satire to display the character of those who use this organization as a medium to gain individual or group benefit. The fact shows that many of them have done that. This Advice then becomes SATIRE - rediculous language /expression for them. Thus, as an effort to stop them, this Advice is presented as the guidance or reference. Moreover, the essence of his expectation is the unity or solidity of NW followers - not separated or isolated due to secular matter/need. Once again, this becomes a Satire for them. His Advice which roughly describes the case is shown in the following Stanzas.

Bila nanda memang behutang Janganlah NW yang harus dilelang

NW bukan milik seorang

Tak boleh dipakai membayar hutang

Janganlah nanda lupa daratan

Karena mendapat kursi jabatan

Kursi ananda diberikan Tuhan

Lantaran jasa Nahdlatul Wathan

Kompak utuh bersatu haluan.. Istiqomah ikhlas kepada Tuhan Itu amanat Maulana Alhasan Kepada warga Nahdlatul Wathan

(If you truly owe

Don't sell NW

NW is not someone's

It's not for paying debt)

(Don't be forgetful 
After occupying position

It is a gift from the God

On the service from NW)

(Compact in one goal

Consistent, sincere to God

So advices Maulana Alhasan

To NW followers)

Three stanzas above are interesting since what is said by Maulana Syekh in each can be clearly seen by the addressee. For example he says that NW is not for sale and paying debt. Nowadays, so many people use NW to get access in many cases especially the ones which are connected to politics. In stanza two above he reminds people who have a "position"not to lose control, but keep remebering instead that his position is from God through NW. The fact shows that many people in the government office are from NW organiztion. In the third stanza he restresses what he has said previously in order that the people are to pay a deep attention on them.

\section{Conclusion}

It is clear that all pieces of the Advice by Maulana Syekh are relevant till nowadays. His sayings - after he passed away - are proven. There have been many proofs inside the organization in particular and West Nusa Tenggara people in general. This Advice book signifies how excellent he is, how great his holiness, profound knowledge, literary art, his love to his NW followers, and his bright future view towards the change of the times. The strong content which is offered in each Advice is relevant to the height of form creativity. To put that in another way, form and content aspects of this work manage to show the good literature strength, so that the readers enjoy not only moral value but also the literary aethetic. Both are meaningful and valuable especially for contemporary society who have become post-modernists. For that reason his work is eligible to be introduced as the guide for everybody. This book can represent the prototype of Indonesia/Malay literary work is has been so far developing at West Nusa Tenggara societies.

\section{Conflicts of Interest}

"The authors declare that there is no conflict of interest regarding the publication of this paper."

\section{Funding Statement}

This article was officially funded by Faculty of Teacher Training and Education, University of Mataram to which we would like to say our special thanks

\section{Acknowledgments}

We are very grateful to God Almighty for His mercy and guidance so that this short paper can finally be accomplished. Then our great thanks go to the rector of University of Mataram and the dean of Faculty of Teacher Training for their encouragement and support for all staffs, to always write scientific papers

\section{References}

[1] Castle, Gregory. 2007. The Blackwell Guide to Literary Theory. Oxford, UK: Blackwell Publishing Ltd.

[2] Effendi, Ahmad. 2015. Catatan Harian Seorang Santri (Studi Kritis Relasi NW dengan Masyarakat Luas). Yogyakarta: Good Governance Institute.

[3] Endraswara, Suwardi. 2003. Metodologi Penelitian Sastra : Epistemologi, Model, Teori, dan Aplikasi. Yogyakarta: Pustaka Widyatama.

[4] Hamzanwadi, Kyai. 2014. Wasiat Renungan Masa Pengalaman Baru. Selong, Lombok Timur: Yayasan Pendidikan Hamzanwadi Pondok Pesantren Darunnahdlatain NW.

[5] Leitch, Vincent B. 1944. American Literary Criticism from the Thirties to the Eighties. New York: Colombia University Press.

[6] Wellek, Rene and Austin Warren. 1977. Theory of Literature. San Diego. Harcourt Brace Javanovich, Publisher.

[7] _ "Nahdhatul Wathan". www.id.wikipedia.org. Retrived on the 14th of August 2014

[8] - "Muhammad Zainul Abdul Majid". www.id.wikipedia.org. Retrieved on the 14th of August 2014.

[9] _. "Maulana Syekh Ditetapkan Sebagai Pahlawan Nasional". www.suarantb.com. Retrieved on the 21 st of November 2017. 